Annales Missiologici Posnanienses t. 24 (2019), s. 41-57

doi: 10.14746/amp.2019.24.3

GRZEGORZ ADAMIAK

Uniwersytet Kardynała Stefana Wyszyńskiego w Warszawie

Wydział Teologiczny

\title{
Kościół katolicki na Islandii do roku 1264
}

\section{Kontekst historyczny}

Rozpoczęty w drugiej połowie IX w. proces zasiedlania odkrytej przez norweskich imigrantów Islandii trwał około 60 lat. Za jego koniec uważa się rok 930, kiedy to powstała niezależna Wspólnota Islandzka z mniej więcej 25-tysięczną populacją. Rządy państwem spoczywały w gestii Althingu (zgromadzenia wolnych obywateli), który zbierał się każdego lata w Dolinie Parlamentu. W praktyce Althing, stanowiący gremium legislacyjne, sądownicze, pełnił także wiele innych funkcji w życiu islandzkiego społeczeństwa. W obliczu niewydolności Althingu, około 30 lat po jego powstaniu, cały kraj podzielony został na cztery dzielnice z lokalnymi zgromadzeniami, ale z uwzględnieniem naczelnej roli tego gremium. To właśnie decyzją Althingu Islandia przyjęła w 1000 r. chrześcijaństwo mające wielkie znaczenie dla kraju, jego integracji i kulturowego rozwoju. Niestety, rezygnacja z silnej, scentralizowanej władzy królewskiej okazała się zgubna w skutkach dla młodego państwa islandzkiego.

Prawie czterysta lat historii niezależnej, islandzkiej wspólnoty narodowej, zakończone jej upadkiem, dzieli się niekiedy na pięć okresów:

1. 874-930: okres zasiedlenia.

2. 930-1030: wiek sag (w tych latach mają miejsce wydarzenia opisane w sagach Islandczyków. Był to niezwykle burzliwy okres w dziejach Islandii).

3. 1030-1120: wiek pokoju (czas, kiedy życie na Islandii stosunkowo się uspokaja a chrześcijaństwo zaczyna się umacniać. Islandia ma swoich pierwszych biskupów, często bardzo wykształconych, światłych, 
zasłużonych na polu polityki. Podaje się, że w tym okresie zaprzestano nawet noszenia broni. Jest to też czas pierwszych thumaczeń obcojęzycznej literatury religijnej, głównie homilii, które wywarły silny wpływ na prozę islandzką).

4. 1120-1230: wiek piśmiennictwa (rozwija się wtedy, i udoskonala, islandzka literatura. Był to czas rozwoju oraz wielkiej, intelektualnej aktywności, zarówno na polu artystycznym, jak i naukowym).

5. 1230-1264: okres Sturlung (swoją nazwę wziął od nazwiska jego najbardziej wpływowej rodziny). Pomimo widocznego kryzysu, powstały w tym czasie jedne $\mathrm{z}$ wartościowszych sag i dlatego, z pewnymi poprawkami, można mówić o nim jako o islandzkim Renesansie (Magnússon 20-21; Rosenblad i Sigurðardóttir-Rosenblad 1993, 14).

Ostatni okres był czasem gwałtownych rozruchów społecznych oraz ścierania się sprzecznych interesów rozmaitych klanów i rodów, co ostatecznie doprowadziło do upadku wolnego państwa. Wewnętrzne konflikty i napięcia pomiędzy lokalnymi przywódcami zachęciły króla Norwegii Hakona IV do tego, by wykorzystując niestabilną sytuację na wyspie, podporządkować w latach 1258-1264 Islandię Koronie Norweskiej i związać się z nią (Wittmann 616; Magnússon 103; Parker 222-225; Rosenblad i Sigurðardóttir-Rosenblad 1993, 26-31).

\section{Organizacja kościelna}

Oddalenie Islandii od europejskiego centrum i ograniczone możliwości komunikacyjne wpłynęły, wkrótce po przyjęciu chrześcijaństwa, na islandzki Kościół. Okoliczności te pozwoliły na wykształcenie się pewnej niezależności i oryginalności chrześcijaństwa na wyspie. Ważnym faktorem było też niewielkie znaczenie, jakie nadawano temu obszarowi. Od momentu przyjęcia chrześcijaństwa aż do połowy XII w. Kościół na Islandii znajdował się w sferze oddziaływania arcybiskupstwa w Hamburgu-Bremie. Przedmiotem szczególnego zainteresowania tego niemieckiego arcybiskupstwa były już w X w. tereny Skandynawii, więc pośrednio także i Islandii, o czym świadczy choćby misyjna wyprawa biskupa Fryderyka (981-986). O wiele jednak ważniejsze były tereny Norwegii, Szwecji i Danii niż odległej i mało znaczącej Islandii. Sytuacja nie zmieniła się znacząco nawet po powstaniu, w 1104 r., biskupstwa w Lund, które miało obejmować wszystkie kraje skandynawskie. Kontakty ze szwedzkim Lund były nieregularne i raczej rzadkie. Przyjaźnie nastawieni arcybiskupi Lund byli gotowi pomagać Islandczykom, ale z pewnością Islandia nie stanowiła obszaru, któremu poświęciliby szczególną uwagę. Bardziej ab- 
sorbowały arcybiskupów Lund sprawy Kościoła w Danii i krajach ościennych (Byock 302).

W 1153 r. powstało oddzielne arcybiskupstwo w Trondheim, w Norwegii. Jurysdykcja arcybiskupa Trondheim rozciągała się na wszystkie diecezje norweskie, a także na Orkady, Hebrydy, Wyspy Owcze, Grenlandię i Islandię. Nie oznaczało to jednak jakiegoś szczególnego i silnego oddziaływania na społeczeństwo islandzkie, choć stosunki układały się raczej poprawnie. Zresztą pod koniec XII w. Kościół w Norwegii przeżywał pewne trudności w relacji z królem norweskim, który został nawet ekskomunikowany, ale niektórzy biskupi musieli opuścić kraj. Sytuacja poprawiła się w XIII w. za panowania króla Hakona IV (1217-1263); miało wtedy miejsce wyraźne współdziałanie króla i hierarchii kościelnej (Byock 302).

Kościół na Islandii podlegał więc najpierw metropolii w Hamburgu-Bremie, następnie skandynawskiemu arcybiskupstwu w Lund, a potem arcybiskupstwu w Trondheim i do połowy XVI w. pozostawał w ścisłej relacji z Rzymem. Kolejni biskupi byli zazwyczaj wybierani przez Althing i wyświęcani przez metropolitę (Wittmann 616). Wydaje się również, że biskupi islandzcy pracowali nad integracją struktur kościelnych w ramach państwa islandzkiego. Aż do 1238 r., kiedy to biskupstwa objęli biskupi bardziej zależni od Kościoła norweskiego, episkopat islandzki reprezentował $\mathrm{i}$ bronił typowo islandzkiej racji stanu (Byock 307).

\section{Akcja misyjna na Islandii}

W pierwszych dekadach po przyjęciu chrześcijaństwa Islandczycy nie mieli zbyt głębokiej wiedzy na temat swojej nowej religii. Chrystianizacji kraju dokonywali stopniowo księża zagraniczni i wędrowni biskupi-misjonarze, którzy przemierzali nowo pozyskany dla chrześcijaństwa kraj. Wylicza się imiennie m.in. misjonarzy-nauczycieli Piotra, Abrahama i Stefana, którzy wymieniani są w literaturze jako biskupi ormiańscy (Byock 303). Z dużym prawdopodobieństwem pojawili się na Islandii misjonarze pochodzący z Bizancjum lub zależnych od niego terenów, nazywani Grekami bądź Ormianami (Parker 387).

Znaczącą rolę w umacnianiu chrześcijaństwa na Islandii odegrała Norwegia. Co prawda w 1000 r. król Olaf Trygvasson poniósł śmierć, a Norwegia zaczęła zmagać się z nawrotem religii pogańskich, jednak kryzys ten został przezwyciężony wraz z objęciem tronu przez Olafa Haraldssona (św. Olaf). Mimo iż nie mógł on podporządkować Islandii politycznie, był zainteresowany religijną kondycją Islandczyków i zaangażował się w umacnianie chrześcijaństwa na wyspie. Źródła podają, że król Olaf wysyłał misjonarzy na Islandię. Jed- 
nym z nich, znanym z imienia, był Bjarnhardur Vilradsson zwany Mądrym, który przebywał na Islandii przez pięć lat około 1020 r. Pochodził przypuszczalnie z Anglii. Kolejnym był biskup Kolur, prawdopodobnie Niemiec, który przybył na wyspę około 1025 r. Największe znaczenie miała jednak wyprawa i obecność biskupa Hróðólfura, wysłanego przez arcybiskupa Bremy. Przybył on najpierw z Anglii do Norwegii, a następnie rezydował, w latach 1030-1049, w Borgarfjörður. Hróðólfur był mnichem benedyktyńskim i założył na Islandii klasztor, który stał się pierwszym ośrodkiem szkolnictwa na wyspie (Njardvík 64-65). To wymagające odnotowania zaangażowanie króla Norwegii w chrystianizację Islandii ilustruje i potwierdza wzniesienie, w 1020 r., kościoła w Thinvellir (Równina Parlamentu), z drewna przysłanego z tego kraju (Torfason 4).

Źródła wspominają wielu innych biskupów-misjonarzy, których obecność stała się nawet powodem niepokojów i zamieszania. Niektórzy z nich byli wędrownymi „misjonarzami”, bez formalnej przynależności do jakichkolwiek struktur kościelnych. Hungrvaka (saga mówiąca o początkach Kościoła na Islandii za rządów pierwszych pięciu biskupów islandzkich) podaje, że jeszcze w okresie istnienia pierwszej diecezji pojawili się na Islandii misjonarze, którzy byli pobłażliwsi i głosili chrześcijaństwo w bardzo zmodyfikowanej i rozmytej formie. Szukając popularności i poparcia, stawali oni często w opozycji do istniejących struktur. W takiej sytuacji zdecydowane stanowisko musiał zająć Adalbertus (1043-1072), arcybiskup Hamburga-Bremy, który wystosował nawet specjalne pismo zakazujące ludziom korzystania $\mathrm{z}$ ich posługi, ponieważ niektórzy z nich byli ekskomunikowani, a wszyscy przybyli na Islandię bez jego pozwolenia (Njardvík 65; Byock 306).

Największą przeszkodą, jaką napotkały wysiłki misyjne, podejmowane w pierwszych dekadach chrześcijaństwa na Islandii, był brak odpowiednio wykształconych księży. Warto podkreślić, że chodzi o duchownych miejscowych, dla których barierą nie byłaby nieznajomość języka. Pomimo więc pracujących gorliwie duchownych angielskich i niemieckich, naglącą potrzebą stało się wykształcenie rodzimego duchowieństwa. Zaczęli to dostrzegać i rozumieć sami Islandczycy, a szczególnie lokalni przywódcy, zainteresowani umacnianiem chrześcijaństwa na podległym im terenie (Njardvík 65).

\section{Pierwsi rodzimi biskupi}

Samodzielne struktury Kościoła na Islandii zaczęły kształtować się w połowie XI stulecia. Gizur Biały, wpływowy i mający duże zasługi dla przyjęcia chrześcijaństwa goði, wysłał swego syna Isleifura (ur. ok. 1006) do szkoły klasztornej w Herford, w Westfalii. Isleifur był pierwszym Islandczykiem, 
który studiował i przyjął święcenia kapłańskie za granicą. Po powrocie do kraju ożenił się i, tak jak jego ojciec, został przywódcą klanu. Kilka lat później, około 1055 r., w trakcie obrad Althingu Isleifura wybrano i ogłoszono biskupem. Po wyborze wyjechał z kraju i w 1056 r. został wyświęcony na biskupa przez arcybiskupa Hamburga-Bremy. Objął biskupstwo w Skálholt (Byock 305-306). Uroczystość miała miejsce 26 maja. Odbyła się w kościele pw. św. Piotra w Herford, tam, gdzie wcześniej Isleifur pobierał nauki. Przed swą konsekracją Isleifur został przyjęty w Rzymie przez papieża Wiktora II (Torfason 5).

Nie ma zbyt wielu danych na temat początków pierwszego biskupstwa i rządów Isleifura, ale wydaje się, że osiągnął on tylko częściowy sukces. Źródła islandzkie (Hungrvaka) mówią, że napotkał sporo poważnych trudności w swoich biskupich rządach, wynikających głównie ze słabo ugruntowanej wiary i nieposłuszeństwa pierwszych pokoleń islandzkich chrześcijan. Przykład braku ugruntowanej wiary, nieposłuszeństwa i niemoralności wiernych Isleifura to przypadek jednego z „przepowiadających prawo”, który poślubił dwie kobiety - matkę i córkę. Sprawowanie rządów biskupich przez Isleifura nie spotkało się z powszechnym i dobrym przyjęciem, a wierni okazywali mu, jako pasterzowi, niewielkie posłuszeństwo i szacunek. Wydaje się, że ze swej stolicy biskupiej musiał on rządzić i nauczać intensywniej niż misjonarze, z którymi zmuszony był swoiście konkurować. Ocena rządów Isleifura jest jednak dwojaka. Adam z Bremy w dziele Gesta Hammaburgensis ecclesiae pontificum (z 1072) pisze, że Islandczycy szanują swojego biskupa, jak gdyby był królem, i cały naród stosuje się do jego zaleceń. $Z$ drugiej strony islandzkie źródła mówią o tym, że musiał on zmagać się z wieloma przeciwnościami, a szczególnie z nieposłuszeństwem swych wiernych. Historykom bardziej prawdopodobna wydaje się druga wersja (Njardvík 65-66; Parker 219).

Po śmierci Isleifura stolicę biskupią w Skálholt objął jego najstarszy syn Gizur Isleifsson. Jego rządy przybrały już inny kształt i cechowała je pozytywna zmiana. Gizur, podobnie jak ojciec, wybrany został na biskupa przez Althing. Hungrvaka podaje, że znalazł on jednak sposób na przezwyciężenie opozycji i zażegnanie problemów, z którymi musiał zmagać się jego poprzednik. Przed zatwierdzeniem wyboru i przyjęciem sakry biskupiej postarał się najpierw o zaakceptowanie wyboru i urzędu przez naczelników poszczególnych klanów w kraju. Był to roztropny krok i potrzebny punkt w obejmowaniu stolicy biskupiej. Następnie udał się do Magdeburga i tam wyświęcony został, we wrześniu 1082 r., na drugiego w historii biskupa Islandii. W czasie swego długiego episkopatu (1082-1118) Gizur cieszył się dużym szacunkiem i owocnie pracował nad umocnieniem pozycji Kościoła w społeczeństwie islandzkim. W czasie jego rządów, w 1096 r., wprowadzona została dziesięcina, a posiadłości rodzinnej farmy w Skálholt, jako jedne z pierwszych, zapisa- 
no na własność Kościoła. Zaprowadzenie dziesięciny na Islandii było pierwszym tego typu zarządzeniem w Europie Północnej. Pozyskiwane z dziesięciny środki dzielono na cztery części: dla biskupa, duchownych, na utrzymanie kościołów i dla biednych. Przejście ziemi z rąk dotychczasowych właścicieli w ręce Kościoła domagało się zgody ze strony spadkobierców i mogło prowadzić do sporów i konfliktów, nie ma jednak mowy o tym, że Gizur napotkał tutaj jakąś opozycję lub trudności (Njardvík 66-67; Byock 305-306).

W tym też czasie ludność z północnej części kraju zaczęła odczuwać potrzebę własnego biskupa, wskutek czego na początku XII w. powstało na Islandii drugie biskupstwo, z siedzibą w Hólar. W 1106 r. duchowieństwo i świeccy wybrali na pierwszego biskupa Hólar Jóna Ogmundarsona. Został on wyświęcony w tymże roku przez arcybiskupa Lund. Biskupstwo w Hólar obejmowało północną część kraju, natomiast dzielnice zachodnie, południowe i wschodnie pozostały w jurysdykcji biskupa Skálholt (Byock 306-307).

Biskup Jón Ogmundarson (1052-1121) studiował prawdopodobnie za granicą. Podkreśla się jego zasługi w dziele wprowadzania chrześcijaństwa do codziennego życia poszczególnych wiernych. Wymagał on od nich, by znali na pamięć Ojcze nasz, Zdrowaś Maryjo i Wierzę. Zalecał każdemu czynienie codziennie znaku krzyża i odmawianie Credo przed posiłkiem i spoczynkiem. Każdy wierny musiał też modlić się siedem razy dziennie oraz regularnie uczęszczać do kościoła. Według niektórych źródeł biskup ten był także przeciwnikiem tańców, które stawały się coraz bardziej popularne na Islandii. Odnosiło się to głównie do tańców, którym towarzyszyły śpiewy o tematyce erotycznej (Njardvík 67-68). Próbował również określać własnymi nazwami dni tygodnia, które w języku islandzkim pierwotnie odnosiły się do bogów. Reforma ta okazała się skuteczna i do dzisiaj w języku islandzkim jedynie nazwy niedzieli i poniedziałku nawiązują do pogańskich korzeni: sunnudagur to „dzień słońca” a mánudagur to „dzień księżyca”. Kolejne nazwy nie mają już pogańskich konotacji: wtorek - priðjudagur (dzień trzeci), środa - miðvikudagur (dzień środkowy), czwartek - fimmtudagur (dzień piąty), piątek - föstudagur (dzień troski, postu), sobota - laugardagur (dzień prania, kąpieli; Parker 220).

Począwszy od czasów Gizura, godność biskupa cieszyła się dużym poważaniem, szacunkiem i znaczeniem. Społeczeństwo islandzkie było społeczeństwem zdecentralizowanym, a chrześcijaństwo stanowiło, ze swą moralnością, czynnik centralizujący i jednoczący. Z drugiej strony waśnie, konflikty, zwłaszcza ich siłowe rozwiązywanie, były normalną i stałą praktyką wśród pierwszych pokoleń Islandczyków. Niezwykle ważną sprawą stawał się więc arbitraż wobec zwaśnionych stron; biskupi oraz inni duchowni byli często rozjemcami i sędziami w sporach. Tak, jak sędziami musieli stawać się lokalni przywódcy, tak roli tej musieli podjąć się również biskupi. Jednym z takich 
liderów, do których wielu zwracało się po radę, był Brand Saemundarson, biskup Hólar w latach 1163-1201 (Njardvík 324-325).

Obydwie stolice biskupie obsadzane były najczęściej przez członków najbardziej wpływowych rodów, stąd nominacje te miały wielokrotnie charakter dalece upolityczniony. Bardzo często biskupi byli przedstawicielami interesów rodów, z których pochodzili. Niejednokrotnie reprezentowali stanowisko klanowe, rodowe, a nie kościelne. Zdarzały się jednak wyjątki będące przejawem autentycznej troski o Kościół i jego reformę. Takim przykładem wśród islandzkiego episkopatu tego okresu jest postać biskupa Thorlaka Thorhallssona (1133-1193). Thorlak pochodził z Hlidarendi na południu Islandii. Został wyświęcony na kapłana w wieku niespełna 20 lat, prawdopodobnie w 1152 r., i rozpoczął kapłańską posługę. Po trzech latach wyjechał do Europy na dalszą naukę. Studiował najpierw w Paryżu, a potem w Lincoln, w Anglii. W czasie pobytu w Europie zetknął się z ruchem reformatorskim papieża Grzegorza VII. Przebywał prawdopodobnie w augustiańskim klasztorze św. Wiktora we Francji. W 1174 r. Klaeng, biskup Skálholt, uzyskał pozwolenie metropolity na wyznaczenie swego następcy. Mając do wyboru trzech kandydatów, wskazał Thorlaka, podkreśliwszy jego przykładny i świątobliwy styl życia. Thorlak był już wtedy opatem pierwszego, założonego zresztą przez siebie, klasztoru o regule augustiańskiej. Akcentowano także zagraniczną edukację Thorlaka i jego zdolności zarządzania finansami, a tego diecezja również potrzebowała, ukończywszy właśnie budowę nowej katedry (Guðmundsson [1]-[2]).

Sakrę biskupią przyjął w Trondheim w dniu 1 czerwca 1178 r. (Torfason 9). Przebywając w Norwegii, Thorlak zapoznał się z obowiązkami spoczywającymi na nim jako biskupie a dotyczącymi wprowadzania w życie idei reformatorskich. Chodziło szczególnie o kwestię kontroli Kościoła, sprawowanej nad jego dobrami, które często znajdowały się w rękach świeckich możnowładców. W czasie swoich rządów w Skálholt Thorlak próbował uniezależnić Kościół od wpływów laikatu, podkreślał niezależny i duchowy wymiar urzędów kościelnych, wskazywał na świętość małżeństwa i wzywał do wierności nauce Kościoła w tym wymiarze. Nauczanie w sprawach moralnych, głównie małżeńskich, nie przysparzało biskupowi popularności i sympatii. Także próba uniezależnienia się od władzy świeckiej spotkała się z dość mocną opozycją ze strony goðar. Na czele opozycji stał Jón Loftsson, który zresztą żył w konkubinacie z siostrą Thorlaka. Mimo nawoływań biskupa konkubinat nie został zerwany, a jednego z synów Jóna uczyniono po śmierci Thorlaka jego następcą. Thorlak nie uzyskał też poparcia ze strony ówczesnego biskupa Hólar (Guðmundsson [6]-[7]; Byock 329-330; Njardvík 72-75).

Podobne zabiegi na rzecz reformy Kościoła i jego dyscypliny podjął biskup Hólar Guðmundur Arason (ur. w 1161, biskup w latach 1203-1237). Za- 
biegał on o uniezależnienie duchowieństwa od władzy świeckiej, co spowodowało także jego konflikt $\mathrm{z}$ tą władzą. Czas rządów Guðmundura przypadł na okres, gdy Europa żyła ideałami ubóstwa i pokory. Osoba Guðmundura zasługuje w tym kontekście na szczególną uwagę. Został wyświęcony na księdza w wieku 24 lat. Charakteryzowała go głęboka duchowość i asceza. Sakrę biskupią przyjął w 1203 r. w Trondheim. Biskup, sam żyjący w ubóstwie, zgromadził wokół siebie wielu naśladowców. Byli wśród nich także ludzie o wątpliwej moralności. Na ich czele pokonał nawet jednego ze swych oponentów - Kolbeinna Tumassona, który zginął w trakcie potyczki ze zwolennikami Guðmundura w 1208 r. Biskup Guðmundur był również uwikłany w spory sądowe ze swoimi przeciwnikami, które ciągnęły się przez kilka lat na forum Althingu. W latach 1214-1218 przebywał w Norwegii. Po powrocie ufundował szkołę. Nie odnotował większych osiągnięć, jeśli chodzi o satysfakcjonujące relacje Kościoła i możnych, ale stał się wzorem i opiekunem dla ubogich. Mimo zakazów, a nawet aresztu domowego, karmił on wielkie tłumy ludzi i wędrował z nimi po terenie diecezji, prowadząc żebraczy styl życia. Domagał się też dla nich wsparcia u właścicieli okolicznych farm. Jednak ten żebraczy ruch wywołał niezadowolenie i obawy ze strony lokalnych przywódców, którzy zbrojnie postanowili położyć mu kres (Byock 334-335; Njardvík 75-78; Parker 221).

Zmierzające ku reformie zabiegi Thorlaka i Guðmundura spotykały się ze sprzeciwem i działaniami możnych świeckich. W związku z tym islandzcy liderzy zaczęli opowiadać się za obsadzaniem stolic biskupich przez kandydatów wygodnych z politycznego punku widzenia, lecz niespełniających kościelnych wymogów wyboru na stolice biskupie. Tymczasem jednym z wymogów było zatwierdzenie kandydata i ordynacja przez metropolitę, który swoją siedzibę miał w norweskim Trondheim. I tak wybranym w $1236 \mathrm{r}$. przez Althing islandzkim biskupom odmówiono wyświęcenia w Norwegii, a w 1238 r. wybory biskupów przeniesiono do Trondheim. Były to kolejne ograniczenia kompetencji możnych posiadających swoje kościoły i roszczących sobie prawo do obsady stolic biskupich. W konsekwencji rozpoczęło to okres obsadzania islandzkich biskupstw przez duchownych i duchownymi spoza Islandii. W latach 1238-1380 spotykamy zaledwie czterech Islandczyków jako biskupów na Islandii. Dodatkowo niewydolność islandzkiego aparatu władzy świeckiej niewątpliwie skłoniła króla norweskiego do interwencji zainicjowanej w latach czterdziestych XIII w., która doprowadziła do kresu islandzką autonomię na początku lat sześćdziesiątych tego stulecia (Njardvík 75-78; Byock 335; Magnússon 103; Torfason 13).

Lista biskupów w okresie niezależnego państwa przedstawia się następująco: 
Dla całego kraju

1. Isleifur Gizurarson (1056-1080)

2. Gizur Isleifsson (1082-1106)

Biskupstwo w Skálholt

1. Gizur Isleifsson (1106-1118)

2. Thorlak Runolfsson (1118-1133)

3. Magnus Einarsson (1134-1148)

4. Klaeng Thorsteinson (1152-1176)

5. Thorlak Thorhallsson (1178-1193)

6. Páll Jónsson (1195-1211)

7. Magnus Gizurarson (1216-1237)

8. Sivard Thettmarsson (Norweg; 1238-1268)

Biskupstwo w Hólar

1. Jón Ogmundarson (1106-1121)

2. Ketil Thorsteinsson (1122-1145)

3. Bjorn Gilsson (1147-1162)

4. Brand Saemundarson (1163-1201)

5. Guðmundur Arason (1203-1237)

6. Botolf (Norweg; 1238-1246)

7. Heinrek Karsson (Norweg; 1247-1260)

8. Brand Jonsson (1263-1264; Byock 357).

\section{Duchowieństwo}

W celu ułatwienia praktykowania nowej religii wielu przywódców klanów i właścicieli farm budowało kościoły na swym terenie i utrzymywało je, jednocześnie uważając je za swoją własność. Między 1030 a 1153 r. była to na Islandii dość powszechna praktyka, znana także z Norwegii. Bardzo często również goðar (pogańscy kapłani) przejmowali obowiązki duchownych chrześcijańskich, co nie tylko pozwalało im utrzymać ich dotychczasowy status, ale nawet go podnieść. W tym pierwszym okresie zdarzały się więc przypadki sprawowania przez lokalnych przywódców władzy świeckiej i posługi religijnej na wzór pogańskich goðar. Historycy wymieniają kilku z nich z imienia (Byock 303).

Dobieranie i ustanawianie „duchownych” dokonywało się też przypuszczalnie w inny sposób. Właściciel kościoła, jego zarządca lub właściciel farmy mógł ustanowić samodzielnie „księdza” do posługi w swoim kościele. 
Aby to uczynić, wystarczyło dojść do porozumienia z - najczęściej zubożałym - młodym człowiekiem, który zgodziłby się wziąć na siebie obowiązki kapłańskie i rozpocząć przygotowanie. W zamian za przygotowanie, a potem zapewnienie utrzymania młodzieniec zobowiązywał się przez całe swe życie pełnić posługę kapłańską dla swego pracodawcy. Ten rodzaj księży nazywany był kirkjuprestar, ale prawdopodobnie nie cieszył się zbyt dużym szacunkiem. W przypadku porzucenia posługi duchowny taki mógł być traktowany na równi ze zbiegłym niewolnikiem. Nie ma zbyt dużo informacji na temat tej grupy duchownych i zdaje się, że owa grupa zanikła dość szybko w XII w. (Byock 303).

Kolejną grupę duchownych stanowili tzw. thingaprestar, funkcjonujący na prawach prywatnych kapelanów. Rekrutowali się z wolnych obywateli, którzy po odpowiednim przygotowaniu podejmowali się obowiązków kapłańskich. Mieli oni często do obsłużenia jeden lub więcej kościołów. Księża tacy stawali się zazwyczaj domownikami właściciela kościoła, zachowując swą osobistą niezależność. Takimi właśnie kapelanami byli przed objęciem urzędu biskupiego Thorlak czy Guðmundur Arason (Byock 303-304).

Duchowni Kościoła na Islandii pozostawali dziećmi swego czasu i swego narodu, stąd nie do końca zależało im na dyscyplinie w Kościele. Część z nich okazywała posłuszeństwo swoim biskupom, ale większość prawdopodobnie uczestniczyła $\mathrm{w}$ partykularnych interesach charakterystycznych dla społeczeństwa islandzkiego. Większość duchownych w tym czasie była żonata i zabiegała o odpowiednie zabezpieczenie swych dzieci. Duchowni regularnie brali udział w rodowych konfliktach i sporach, przyjmując niekiedy na siebie funkcje arbitrów, sędziów bądź po prostu stronników swoich krewnych czy sprzymierzeńców. Zdarzało się również, że podczas sporu biskupa z możnymi duchowni nie popierali swego przełożonego, ale stawali po stronie skonfliktowanych, a nawet suspendowanych możnych. Tak było np. w 1208 r. w czasie konfliktu z udziałem biskupa Guðmundura Arasona (Byock 336).

O nadużyciach czy wykroczeniach wśród duchownych islandzkich dowiadujemy się choćby z listu arcybiskupa Trondheim, z 1173 r., skierowanego do biskupów, możnych i ludu Islandii. Pisze w nim, że, niezależnie od stopnia święceń, duchowni, którzy dopuścili się zabójstwa, nie mogą pełnić dalej swych funkcji. Duchowni nie mogą też podejmować się roli oskarżycieli w procesach sądowych, za wyjątkiem sytuacji, kiedy reprezentują niezdolnych do tego krewnych, sieroty lub bezbronne, dotknięte ubóstwem kobiety. Sturlunga saga, a nawet Saga o biskupie Thorlaku dostarczają wielu przykładów konfliktów, w które zaangażowali się islandzcy duchowni tego okresu (Byock 336-337).

Koniecznie trzeba jednak dodać, że wielu spośród duchownych było ludźmi wykształconymi, którzy zdobywali wiedzę na uniwersytetach francuskich 
i angielskich. Wielu spośród nich podróżowało i pielgrzymowało po całej Europie. Należy też podkreślić ich zasługi dla islandzkiej edukacji i rozwoju kultury (Wittmann 616).

\section{Życie monastyczne}

Klasztory na Islandii nie odgrywały, w przeciwieństwie do Europy kontynentalnej, większej roli politycznej czy ekonomicznej, ale wywarły duży wpływ na islandzkie życie kulturalne epoki. Zwłaszcza ostatnie badania potwierdzają, że klasztory odegrały ogromną rolę choćby w rozwoju piśmiennictwa i w samym powstaniu islandzkich sag. Trzeba, rzecz jasna, pamiętać o tym, że klasztory islandzkie nie były duże. Zdaniem Einara Sveinssona, istniejące do 1300 r. wspólnoty były raczej niewielkie i liczyły zazwyczaj od 5 do 10 mnichów. Wspólnoty mnisze zakładano na Islandii według reguły benedyktyńskiej lub augustiańskiej. Nie miały też one charakteru międzynarodowego, ale swoich członków rekrutowały spośród rodzimej ludności. Być może brało się to także z fundowania i utrzymywania wspólnot przez lokalnych możnowładców, którzy niekiedy sami na koniec życia osiadali w klasztornych murach (Byock 338).

Pierwsze próby założenia klasztoru na Islandii miały prawdopodobnie miejsce w latach 1030-1049. Wtedy to na wyspie przebywał Hróðólfur, angielski biskup, wysłany na Islandię przez arcybiskupa Bremy. Uważa się go za założyciela życia monastycznego na Islandii. $Z$ jego imieniem łączy się powstanie pierwszego klasztoru i szkoły przyklasztornej w Bæ w Borgarfjörður (Torfason 5; Rosenblad i Sigurðardóttir-Rosenblad 1993, 25).

Nie wszystkim fundacjom udało się niestety przetrwać, a koniec niektórych był tragiczny. Tak było w przypadku próby założenia klasztoru na Vestmannaeyjar. Biskup w Skálholt Magnus Einarsson zakupił tam ziemię z zamiarem ufundowania klasztoru. W $1148 \mathrm{r}$. został jednak spalony wraz z 72 ludźmi w Hitardal. Po owym wydarzeniu zrezygnowano z dalszych planów ufundowania klasztoru w tym miejscu (Torfason 8).

Islandzkie klasztory były centrami nauki i kulturowego oddziaływania. Najwięcej informacji $\mathrm{z}$ tego okresu zachowało się o benedyktyńskim klasztorze w Thingeyrar, w granicach diecezji Hólar. Był to pierwszy klasztor, założony być może w 1112 r., który przetrwał i stał się miejscem o dużym wpływie kulturowym. Mnisi z tego klasztoru koncentrowali się głównie na dziełach hagiograficznych. To spod ich pióra wyszły najwcześniejsze sagi o królu Olafie Tryggvassonie i św. Olafie. Był to także ośrodek popularyzujący osobę pierwszego biskupa Hólar - Jóna Ogmundarsona. W latach 1185-1188 opat Thingeyrar Karl Jonsson przebywał w Norwegii. W czasie owego 
pobytu rozpoczął pisanie Sagi o Swewirze - królu norweskim. To naukowe i kulturalne nastawienie klasztoru w Thingeyrar przyczyniło się zapewne do jego docenienia przez biskupa Jóna, który przeznaczał dla wspólnoty część dziesięciny z diecezji. Klasztor posiadał również majątek zapewniający mu obfitość ryb i urodzajnych pastwisk. Miał także prawo do gromadzenia drewna wyrzucanego na brzeg przez morze (Byock 339-340). Drewno pochodzące z Syberii było niezwykle wartościowym materiałem. Prawa do jego zbioru stanowiły cenne źródło dochodów, a niejednokrotnie też przedmiot zaciętych sporów i konfliktów (Parker 204).

Pozostałe klasztory nie mogły jednak uchodzić za szczególnie bogate i często zmagały się z dużymi przeciwnościami. Być może po niektórych nie pozostał nawet ślad. Późny start życia monastycznego i jego słaby rozwój w epoce niezależnego państwa islandzkiego spowodował, że nie wywarło ono zbyt dużego wpływu pozakulturalnego. Drugim klasztorem w północnej części kraju była wspólnota w Munkathvera. Klasztor założony został w $1155 \mathrm{r}$. i przetrwał 396 lat. Drugi opat tego klasztoru - Nikulas Bergsson - udał się na pielgrzymkę do Rzymu i Jerozolimy oraz napisał nawet specjalny przewodnik dla pielgrzymujących w tamte strony (Torfason 8 ).

Trzecim miejscem, gdzie w 1200 r. powstał ośrodek życia zakonnego, był Saubær. Fundacja ta przetrwała jednak zaledwie 12 lat. W diecezji Skálholt pierwszy klasztor ufundowany został około 1166 r. w Hítardalur. Przetrwał on do około 1200 r. (Byock 340). Drugim klasztorem na południu był założony przez Thorlaka klasztor w Thykkvibær. Wspólnota powstała w $1168 \mathrm{r}$. Thorlak był tam najpierw przeorem, a następnie opatem. Wspomina się, że jako przełożony Thorlak cieszył się wielkim szacunkiem, a fundacja przyciągała mnichów także z innych klasztorów. Podkreśla się również wzorową wierność regule, pielęgnowaną $\mathrm{w}$ Thykkvibær. Klasztor był też miejscem, które wywarło wpływ na islandzką literaturę i ją ubogaciło (Guðmundsson [4]-[5]).

Kolejnym, erygowanym w tym czasie klasztorem była wspólnota założona w 1172 r. na wyspie Flatey. Fundację tę przeniesiono w 1184 r. do Helgafell. Ostatni klasztor ufundowany został w 1226 r. na wyspie Viðey. Fundacje w Thingeyrar, Munkathvera, Kirkjubær (pozostała po mnichach iroszkockich) założono, opierając się na regule benedyktyńskiej. Wspólnoty w Thykkvibær, Flatey, Viðey i prawdopodobnie w Saubær stosowały się do reguły św. Augustyna (Byock 340).

Przed rokiem 1300 podaje się w źródłach imiona sześciu kobiet uznawanych za mniszki. Jest to jednak zagadnienie dyskusyjne, gdyż wszystkie spośród nich prowadziły życie świeckie, będąc nawet żonami biskupów czy wychodząc kilkakrotnie za mąż i dopiero pod koniec życia wybierając zakon lub pustelnię (Byock 304). Wspomina się więc np. Gudrun - pierwszą kobietę-pustelnicę po przyjęciu chrześcijaństwa, która w 1070 r. odbyła pielgrzym- 
kę do Rzymu. Znana jest również w źródłach Hidur, zakonnica, która w latach 1106-1121 prowadziła życie pustelnicze (Torfason 6; 7).

Należy zachować tym większą ostrożność w kwestii funkcjonowania przed 1264 r., na Islandii, zaledwie jednego klasztoru żeńskiego. Założono go, a w zasadzie oparto na wcześniejszej bazie klasztoru iroszkockiego, w $1186 \mathrm{r}$. w Kirkjubær. Wskutek trudności finansowych przeszedł w 1218 r. pod kontrolę biskupstwa w Skálholt i wkrótce został zamknięty. Fundację odnowiono pod koniec XIII w. (Byock 340).

\section{Islandzcy święci}

Przez pierwsze dwieście lat chrześcijaństwa na Islandii wierni czcili świętych z innych krajów, o których to świętych nauczał Kościół. Z czasem jednak pobożność wiernych zaczęła poszukiwać rodzimych przykładów świętości i orędowników w trudnych sytuacjach życiowych. Pierwsze wieki chrześcijaństwa dały Kościołowi na Islandii trzech orędowników powszechnie czczonych i uważanych za świętych. Ich „posiadanie” było bardzo ważne i umacniało wiarę.

Pierwszym i najpopularniejszym, choć oficjalnie ogłoszonym dopiero w 1984 r. przez Jana Pawła II, jest biskup Thorlak. Już kiedy żył, cieszył się wielkim szacunkiem wiernych oraz powszechnie uznawano i podkreślano świętość jego życia. Cuda zaczęto przypisywać mu wkrótce po śmierci. Jednym z nich była interwencja Thorlaka na rzecz mieszkańców północnej części wyspy. Pod koniec XII w. panujące ochłodzenie spowodowało, że wszystkie porty na północy kraju zablokowała dryfująca kra. Popularne stało się w takich sytuacjach wzywanie pośrednictwa Świętego Biskupa. Niedługo po jego śmierci, w 1198 r., potwierdzenie cudów i kult Thorlaka zaaprobował Althing, a biskup Skálholt - Páll Jónsson - zezwolił na wzywanie swego poprzednika jako świętego (Njardvík 79).

W dniu 20 lipca 1198 r. ciało Thorlaka ekshumowano i przeniesiono do katedry w Skálholt. Latem 1199 r., w czasie obrad Althingu, uchwalono, że uroczystość ku czci Świętego Biskupa będzie przypadać w dzień jego śmierci - 23 grudnia. W 1237 r. postanowiono ponadto, iż doroczne wspomnienie świętego będzie także obchodzone 20 lipca, w rocznicę przeniesienia relikwii Thorlaka do katedry w Skálholt. Biskup Thorlak jest niezwykle popularny i mocno zakorzeniony w duchowej kulturze Islandii. Jest również znany i czczony w Norwegii, Danii, Szwecji, na Wyspach Owczych i Wyspach Brytyjskich. Sława św. Thorlaka dotarła nawet do Konstantynopola, mianowicie dzięki członkom cesarskiej gwardii przybocznej, złożonej częściowo z mieszkańców północnej Europy (Parker 387-390). Co więcej, niektóre źró- 
dła podają, że w stolicy Cesarstwa Wschodniego wzniesiono, po jednym ze zwycięstw odniesionych przez gwardię wareską, kościół ku czci św. Thorlaka (Guðmundsson [7]-[9]).

Drugą postacią zaliczaną do islandzkiego panteonu świętych jest biskup Jón Ogmundarson. Był on pierwszym biskupem Hólar. Podczas srogiej zimy 1199/1200 r. pewna kobieta miała wizję, w której zapowiedziana została poprawa sytuacji, jeśli tylko szczątki biskupa Jóna będą ekshumowane. Na najbliższym posiedzeniu Althingu zdecydowano, że pierwszy biskup Hólar może być czczony i wzywany jako święty. Powoływano się tutaj na świętość jego życia i pasterską gorliwość, z jaką pełnił swój urząd. Jón Ogmundarson nie cieszy się jednak tak wielką sławą jak Thorlak i nigdy oficjalnie nie został kanonizowany (Njardvík 79).

Również niekanonizowanym, ale cieszącym się wielkim szacunkiem i określanym jako ,święty” jest biskup Guðmundur Arason zwany Dobrym. Nigdy też nie zezwolono oficjalnie na wzywanie jego pośrednictwa na Islandii. Niemniej jednak w 1315 r. ekshumowano jego szczątki, a wierni spontanicznie zaczęli wzywać go jako świętego. W pamięci pozostają przede wszystkim: jego ascetyczny styl życia i dzieła miłosierdzia. Pamięć o nim jest niezwykle żywa i obecna w wielu islandzkich opowiadaniach i ludowych przekazach, które podkreślają jego pomoc świadczoną ubogim i cuda (Njardvík 79).

$\mathrm{Z}$ postacią tego biskupa wiąże się także znajdujące się na półwyspie Snæfellsnes miejsce zwane Mariulind (,zdrój Maryi”). Według tradycji biskup Guðmundur ujrzał tutaj, wiosną 1230 r., Najświętszą Maryję Pannę w towarzystwie trzech aniołów. Maryja poprosiła go o poświęcenie znajdującego się tam źródełka, które od tego czasu nigdy nie wyschło. W przekonaniu wiernych woda ma właściwości lecznicze, zwłaszcza w chorobach oczu. Obecnie miejsce to stanowi cel pielgrzymek diecezjalnych (Herrmann 42-43).

\section{Znaczenie przyjęcia chrześcijaństwa}

Wraz z przyjęciem chrześcijaństwa Islandia i jej mieszkańcy zdecydowali się wejść w orbitę cywilizacji zachodniej. Kościół, w którego dziedzictwie odtąd Islandia partycypowała, wprowadzał peryferyjny kraj w wir wydarzeń mających miejsce zazwyczaj bardzo daleko, ale oddziałujących na wielką, ponadnarodową skalę. To włączenie w ogromne dziedzictwo kulturowe chrześcijańskiej Europy jest dla narodu islandzkiego bezcenne. Pierwszym z kulturowych dobrodziejstw była łacina pozwalająca na utrwalenie i komunikatywny przekaz islandzkiego dziedzictwa kulturowego. Przejęcie alfabetu łacińskiego przyczyniło się w dużej mierze do spisania w 1117 r. całości ustanowionego prawa. Umożliwiło również zapoznanie się z dorobkiem kulturowym chrześci- 
jaństwa i antyku. Pozwoliło także na pełne uczestniczenie w kulturowej wymianie w granicach średniowiecznej christianitas (Nordal i Kristinsson 1996, 66).

W 1030 r. na pielgrzymkę do Rzymu udał się poeta Sigvatr Thórðarson. Przyjmuje się, że jest to pierwsza pielgrzymka z Islandii do Wiecznego Miasta. Wiadomo ponadto, że w XI i XII w. na podobną pielgrzymkę udało się wielu Islandczyków i przynajmniej trzy Islandki (Torfason 5).

Można śmiało już wskazać wyraźne i silne ślady z początku XII w., jakie chrześcijaństwo odcisnęło w islandzkiej kulturze. Zaczęły się ożywione i ubogacające kontakty ze znacznie szerszym światem zewnętrznym; dotychczas relacje te ograniczały się niemal jedynie do Norwegii. Chrześcijaństwo przyczyniło się również do zachowania i utrwalenia tego, co specyficzne i właściwe tylko dla Islandii, a przekazane cywilizacji zachodniej w sagach.

Przyjęcie chrześcijaństwa skutkowało także korzyściami na polu edukacji. W powstałym w $1056 \mathrm{r}$. biskupstwie bardzo szybko założona została przez pierwszego biskupa szkoła, która wywarła istotny wpływ na kulturalne życie całego narodu. Biskup Isleifur może być śmiało nazywany pierwszym nauczycielem Islandii (Trial 14).

Również pierwszy biskup diecezji Hólar może być uważany za pioniera na polu edukacji. On także założył w swej stolicy biskupiej szkołę katedralną. Przygotowywała ona przede wszystkim przyszłych duchownych, ale oddziaływała w konsekwencji na całość społeczeństwa. Zagraniczni nauczyciele prowadzili zajęcia z czytania, pisania, łaciny, śpiewu oraz z kompozycji. Poziom wychowania muzycznego był podobno tak wysoki, że wiedzę zdobywali tutaj nawet zagraniczni uczniowie. Prawdopodobnie to Jón Ogmundarson był założycielem klasztoru w Thingeyrar, który odegrał znaczącą rolę w rozwoju islandzkiej literatury (Njardvík 68).

Także klasztory były w tym okresie ważnymi centrami na mapie placówek oświatowych i kulturalnych. Nauczanie proponowane przez szkoły klasztorne bazowało na chrześcijańskiej doktrynie i służyło przede wszystkim zakorzenieniu nowej religii w społeczeństwie. Na pewno jednak Kościół położył na polu edukacji, w pierwszym okresie chrześcijaństwa, ogromne zasługi. $\mathrm{Na}$ początku XIII w. w całym kraju istniało 330 kościołów obsługiwanych przez 420 księży: 220 kościołów (i 280 duchownych) w diecezji Skálholt oraz 110 kościołów (i 140 duchownych) w diecezji Hólar. Pozwala to przypuszczać, że corocznie kościelne szkoły opuszczało około 20 księży. Wielu spośród ich absolwentów nie musiało też wkraczać na drogę kapłańską, ale mogło podejmować pracę i służbę na innych polach życia społecznego. Nauczanie obejmujące łacinę, gramatykę, śpiew, kompozycję wierszy i kazań czy przemówień mogło bowiem przygotowywać także do służby świeckiej. Taką edukację odebrał choćby Snorri Sturluson, autor Eddy prozaicznej, zasłużony dla kultury i języka islandzkiego (Trial 14). 
Trudno jest w pełni ukazać wpływ chrześcijaństwa i szkolnictwa tego okresu na ewolucję kulturalną i konsolidację narodu. Czas wolnego i niezależnego państwa był okresem największego rozkwitu, rozwoju i najcenniejszych pomników islandzkiej kultury. Chrześcijaństwo stawiało też edukację i kulturę Islandii na najwyższym poziomie w tej części Europy. Ostatnie kilkadziesiąt lat istnienia niepodległego państwa naznaczone było już jednak widmem nadchodzącego upadku i utraty niezależności (Trial 15).

Przyjęcie chrześcijaństwa jest więc $\mathrm{w}$ historii Islandii momentem niezwykle doniosłym, a jego wprowadzanie i umacnianie łączy się z okresem jej świetności, który pozwolił na stałe i oryginalne uczestniczenie tego niewielkiego narodu w wielkiej historii.

\section{CATHOLIC CHURCH IN ICELAND UNTIL 1264}

\section{A B S T R AC T}

The missionary action in Iceland did not end with the reception of Christianity by Althing in the year 1000. Further efforts of the missionaries and their cooperation with Icelandic society were necessary to consolidate the adopted faith. The missionaries from Germany and England first had a huge share here. Then, the native bishops and clergy took over this role successfully. The political and social stabilization of this period allowed Christianity to take root in the society of the Icelandic time of the independent Icelandic Community. This was confirmed by the rise and development of monastic life, the development of Icelandic culture and education. The first period of Christianity in Iceland allowed for laying solid foundations on which, even after the loss of sovereignty, Icelanders could preserve their cultural identity and national heritage.

Keywords: missionaries in Iceland; church structures; episcopate; clergy; monastic life; education

Słowa kluczowe: misjonarze na Islandii; struktury kościelne; episkopat; duchowieństwo; życie monastyczne; edukacja

\section{BIBLIOGRAFIA}

Byock, Jesse. Viking age Iceland. London: Penguin Books, 2001.

Guðmundsson, Gunnar Freyr. Thorlakur helgi. Life, work and influence of st. Thorlak (1133-1193) patron saint of Icelandic people. Trans. Guðmundsson Reynir. Reykjavik: Pilo, 1996. 
Island. Diasporakirche in wilder Natur. Ed. Alfred Hermann. Bonifatius Werk. Bmr.

Magnússon, Sigurdur. Northern Sphinks. Iceland and Icelanders from settlement to the present. London: C. Hurst and Company, 1977.

Njardvík, Njörður. Birth of a nation. The story of the Icelandic Commonwealth. Trans. John Porter. Reykjavík: Iceland Review, 1978.

Nordal, Jóhannes. Kristinsson, Valdimar. Iceland. The Republic. Reykjavík: The Central Bank of Iceland, 1996.

Parker, Philip. Furia ludzi północy. Dzieje świata wikingów. Tłum. Norbert Radomski. Poznań: Dom Wydawniczy Rebis, 2018.

Rosenblad, Esbjörn. Sigurðardóttir-Rosenblad, Rakel. Iceland from Past to Present. Trans. Alan Crozier. Reykjavík: Mál og menning, 1993.

Scherman, Katharine. Iceland: daughter of fire. London: The Travel Book Club, 1977.

Torfason, Ólafur. Kapólskur annáll Íslands: ártöl sem tengjast sögu rómversk-kapólskrar kirkju á Íslandi. Reykjavík: Porlákssjóður, 1993.

Trial, Georg. History of education in Iceland. Cambridge: W. Heffer and Sons LTD, 1945.

Wittmann, Pius. „Iceland.” The Catholic Encyclopedia. Vol. 7. New York: Robert Appleton Company, 1910: 615-617.

Grzegorz Adamiak, kapłan diecezji płockiej, doktor teologii w zakresie misjologii, duszpasterz polonijny na Islandii, administrator parafii pw. św. Jana Pawła II w Ásbrú. 
